Научная статья

УДК 340.132(470)

https://doi.org/10.24866/1813-3274/2021-3/166-182

\title{
ПРАВОВАЯ ОПРЕДЕЛЁННОСТЬ В ПРАКТИКЕ КОНСТИТУЦИОННОГО СУДА РОССИЙСКОЙ ФЕДЕРАЦИИ
}

О. Е. Шишкина ${ }^{1}$, Дальневосточный федеральный университет,

г. Владивосток, Россия.

E-mail: shishkina.oe@dvfu.ru

С. С. Бурцева ${ }^{2}$, Дальневосточный федеральный университет,

г. Владивосток, Россия.

E-mail: burtceva.ss@dvfu.ru

Аннотация: Статья посвящена категории «правовая определённость», которая занимает важное место в юридической аргументации при принятии своих решений Конституционным Судом Российской Федерации. В статье обзорно приведены сложившиеся в российской юридической науке подходы к пониманию правовой определённости. Институциональное развитие конституционного контроля в связи с принятием Конституции Российской Федерации в 1993 г., влияние практики Европейского Суда по правам человека, обмен опытом с органами конституционного правосудия зарубежных стран привели к развитию способов и приёмов юридической аргументации, в том числе идее правовой определённости. Авторы статьи выясняют содержание и значение правовой определённости в аргументации Конституционным Судом своих правовых позиций. Основное предназначение правовой определённости заключается в предотвращении произвольного толкования и применения правовой нормы, защиты прав участников соответствующих правоотношений и неизменность их правового статуса. Тем не менее, явление правовой определённости не ограничивается указанным содержанием. В результате проведённого исследования авторы приходят к выводу, что понятие правовой определённости рассматривается Конституционным Судом в различных, но взаимосвязанных значениях (в частности, «принцип», «требование», «состояние», «степень» и др.). Содержание правовой определённости как принципа включает в себя такие требова-

\footnotetext{
${ }^{1}$ Ольга Евгеньевна Шишкина, кандидат юридических наук, доцент кафедры конституционного и административного права Юридической школы Дальневосточного федерального университета, г. Владивосток, Россия.

${ }^{2}$ Светлана Сергеевна Буриева, магистрант кафедры конституционного и административного права Юридической школы Дальневосточного федерального университета, г. Владивосток, Россия.

(C) Шишкина О. Е., Бурцева С. С., 2021
} 
ния, как формальная опредёленность, предсказуемость правового регулирования и предвидение правовых последствий, стабильность и свойство «res judicata». Авторы подчёркивают, что категория «правовой определённости» имеет перспективы выхода за пределы конституционного правосудия и использования как в правотворческой деятельности, так и в практике других судов.

Ключевые слова: Конституционный Суд Российской Федерации, Конституция, конституционный контроль, конституционное правосудие, юридическая аргументация, правовая определённость, формальная определённость, предсказуемость правового регулирования, res judicata.

Для изитирования: Шишкина О. Е., Бурцева С. С. Правовая определённость в практике Конституционного Суда Российской Федерации // Азиатско-Тихоокеанский регион: экономика, политика, право. 2021. № 3. С. 166-182. https://doi.org/10.24866/18133274/2021-3/166-182.

Original article

\section{LEGAL CERTAINTY IN THE PRACTICE OF THE CONSTITUTIONAL COURT OF THE RUSSIAN FEDERATION}

Olga E. Shishkina ${ }^{1}$, Far Eastern Federal University, Vladivostiok, Russia E-mail: shishkina.oe@dvfu.ru

Svetlana S. Burtseva ${ }^{2}$, Far Eastern Federal University, Vladivostiok, Russia E-mail: burtceva.ss@dvfu.ru

Abstract: This article is devoted to the category of "legal certainty", which occupies an important place in legal argumentation of the Constitutional Court of the Russian Federation. The article provides an overview of approaches to legal certainty in the Russian legal science. Institutional development of constitutional control connected with the adoption of the Constitution of the Russian Federation in 1993, the influence of the practice of the European Court of Human Rights, exchange of experience with constitutional justice bodies of foreign countries have led to the development of methods and techniques of legal argumentation, including the idea of legal certainty. The authors of this article clarify the content and significance of the legal certainty of the Court's argumentation of its

\footnotetext{
${ }^{1}$ Olga E. Shishkina, Candidate of Law, Associate Professor of the Department of Constitutional and Administrative Law, Far Eastern Federal University, Vladivostiok, Russia.

${ }^{2}$ Svetlana S. Burtseva, Master's Degree Student, of the Department of Constitutional and Administrative Law, Far Eastern Federal University, Vladivostiok, Russia.
} 
decisions and legal positions. The main purpose of legal certainty is to prevent arbitrary interpretation and application of legal rules, to protect the rights of participants in the relevant legal relationship and the invariability of their legal status. However, the phenomenon of legal certainty is not limited to the specified content. As a result of the study, the authors have come to the conclusion that the concept of legal certainty is considered by the Constitutional Court in different but interrelated meanings (in particular, "principle", "requirement", "state", "degree", etc.). The content of legal certainty as a principle includes requirements such as formal certainty, predictability of legal regulation and foreseeing legal consequences, stability and the property of res judicata. The authors emphasize that the category of "legal certainty" has the prospects of going beyond the limits of constitutional justice and using it both in law-making and in the practice of other courts.

Keywords: Constitutional Court of the Russian Federation, Constitution, constitutional review, constitutional justice, legal argumentation, legal certainty, formal certainty, predictability of legal regulation, res judicata.

For citing: Shishkina O. E., Burtseva S. S. Legal certainty in the practice of the Constitutional Court of the Russian Federation // PACIFIC RIM: Economics, Politics, Law. 2021. No. 3. P. 166-182. https://doi.org/10.24866/1813-3274/2021-3/166-182.

\section{Введение}

Научный интерес к вопросам конституционного правосудия в России, безусловно, всегда был и остаётся высоким, хотя и меняет свои ракурсы. В период становления конституционного контроля, несомненно, актуальными были вопросы теории и конституционного контроля $[13 ; 20]$, вопросы статуса Конституционного Суда Российской Федерации (далее по тексту - Конституционный Суд), места и роли его решений и правовых позиций в правовой системе России [3]. Далее по мере стабильной работы органов конституционного правосудия учёные обратили свой взгляд на вопросы, связанные с конституционной аргументацией [6]. Принятие в 2020 г. поправок к Конституции Российской Федерации (далее по тексту Конституция) и изменений в Федеральный конституционный закон «О Конституционном Суде Российской Федерации» ${ }^{1}$ актуализировало вновь институциональные и процессуальные вопросы деятельности Конституционного Суда. Часть юридического научного сообщества не замедлила высказать опасения за будущее конституционного правосудия в России [10]. Между тем, вопросы юридической аргументации, являясь частью внутренней интеллектуальной деятельности Конституционного Суда, в меньшей степени подвержены влиянию со стороны законодателя. Более того, способы и приёмы юридической аргументации способны не только

\footnotetext{
${ }^{1}$ В настоящей статье все правовые акты приведены по СПС «Консультант плюс».
} 
проникать из практики международного и зарубежного правосудия в практику национального конституционного контроля, но и выходить далеко за пределы конституционного правосудия внутри государства. В этом аспекте высокий потенциал имеет правовая определённость, идея которой занимает важное место в аргументации при вынесении Конституционным Судом своих решений.

Как отмечает Н. В. Витрук, а также ряд других учёных, «впервые принцип правовой определённости был сформулирован в постановлении Конституционного Суда РФ от 25.04.1995 № 3-П». В указанном постановлении Конституционный Суд рассматривал неопределённость как произвольное понимание содержания правовой нормы [4, с. 270; 5; 7, с. 250-251].

В дальнейшем данная позиция нашла своё подтверждение в постановлении Конституционного Суда от 15.07.1999 № 11-П, согласно которому «критерий определённости правовой нормы как конституцчионное требование к законодателю был сформулирован в постановлении Конституционного Суда от 25.04.1995 № 3-П». Кроме того, в рассматриваемом постановлении впервые сформулированы такие признаки общеправового критерия определённости, как ясность, недвусмысленность правовой нормы, происхождение из конституционного принципа равенства всех перед законом и судом (ч. 1 ст. 19 Конституции).

Первые отсылки к идее правовой определённости появились ещё на первом этапе становления конституционного правосудия в России, до возобновления деятельности Конституционным Судом на основе новой Конституции и нового законодательства о Конституционном Суде. Такой критерий правовой определённости, как неоднозначность правового регулирования, стал востребован Конституционным Судом при принятии им постановления от 30.11.92 № 9-П. Так, при оценке конституционности Указа Президента от 25.08.1991 «Об имуществе КПСС и Коммунистической партии РСФСР» Конституционный Суд пришёл к выводу о наличии правовой неопределённости в ситуации, когда невозможно определить собственника значительной части имущества, принадлежавшего КПСС и Коммунистической партии РСФСР, так как возникла неясность в отношении того, где кончается собственность одного субъекта и начинается собственность другого, а также в некоторых случаях и в отночении того, кто является собственником.

Кроме того, в 1993 г. было вынесено ещё два постановления, в которых поднимались вопросы неопределённости юридического содержания. Так, в постановлении от 12.02.1993 № 3-П Конституционный Суд посчитал необходимым признать не имеющзим юридического значения используемого в Указе Президента РФ от 28.10.1992 года № 1308 понятия «экстремистские элементыл», поскольку оно не имеет определённого юридического содержания. В итоге фактически после принятия постановления абз. 3 п. 2 рассматриваемого Указа, предусматривающего обязанность председателей правительств республик и глав администраций иных субъектов РФ принять строжайшие ме- 
ры к пресечению деятельности экстремистских элементов, не мог подлежать исполнению ввиду имеющейся неопределённости данной нормы.

Дальнейшее институциональное развитие конституционного контроля в связи с принятием Конституции, влияние практики Европейского Суда по правам человека, обмен опытом с органами конституционного правосудия зарубежных стран привели к развитию способов и приёмов конституционной аргументации, в том числе, идее правовой определённости, которая впоследствии вышла за пределы практики Конституционного Суда. Будучи выведенной Конституционным Судом из принципа равенства всех перед законом и судом, предусмотренного в ч. 1 ст. 19 Конституции, правовая определённость в 2020 г. получила законодательное закрепление как принцип, обеспечивающий стабильность правового регулирования. Согласно статье 7 Федерального закона от 31.07.2020 № 247-Ф3 «Об обязательных требованиях в Российской Федерации» принцип правовой определённости выражается в ясном, логичном содержании требований, понятном как правоприменителю, так и иным лицам, которое не должно приводить к противоречиям при их применении, а также должно быть согласованным с целями и принцами законодательного регулирования той или иной сферы и правовой системы в целом. Внедрение данного принципа в законодательство следует оценить, на наш взгляд, позитивно, поскольку таким образом правовая определённость выходит за пределы конституционного правосудия и аргументации, получая легальные основания для применения в правотворчестве и практике других судов.

Конституционный Суд в своих решениях неоднократно подчёркивал основное предназначение правовой определённости, заключающееся в предотвращении произвольного толкования и применения правовой нормы, защите прав участников соответствующих правоотношений и неизменности их правового статуса (см., например, постановление Конституционного Суда от 16.10.2012 № 22-П). Тем не менее, явление правовой определённости не ограничивается указанным содержанием. Более того, в науке отсутствует единство мнений по вопросу того, что в целом представляет из себя правовая определённость и какие элементы она содержит. Орган конституционного контроля при решении дел применяет рассматриваемую категорию также в различных смыслах. В связи с этим уточнение правовой природы и содержания правовой определённости является актуальной задачей, которую попытались решить авторы настоящей статьи.

II. Основные подходы к пониманию категории «правовая определённость». К вопросу о том, что в целом представляет из себя правовая определённость, сложились различные подходы в юридической науке и конституционноправовой практике.

Так, наиболее распространённой точкой зрения является понимание правовой определённости как принципа, в частности, указывается, что «правовая определённость представляет собой общеправовой универсальный принции, действие которого распространяется на все сферы правового регулирования, все отрасли права 
и законодательства, обладающий постоянным действием и имеющий общеобязательное значение для всех субъектов права» [12, с. 254].

Другие авторы полагают, что «вернее было бы говорить об особом сочиальном явлении, имеющем своё развитие в ряде правовых принципов, направленных на обеспечение стабильности правового регулирования общественньх отношений» [19, с. 50].

А. И. Сидоренко разделяет правовую определённость на свойство права и принцип права, придавая им разное значение. Он полагает, что «как свойство права правовая определённость подразумевает точность правовых предписаний, обеспечиваемую высоким качеством юридической техники, при этом как приниип права она требует ясности в объёме субъективных прав, обязанностей и запретов, вытекающей из закона, других форм права, и правоприменительных актов» [17, с. 11]. Д. С. Велиева и М. В. Пресняков указывают, что «правовая определённость представляет собой не технико-юридическое свойство права самого по себе, а определённое качество правового регулирования» [2, с. 6]. Более того, точка зрения о том, что правовая определённость представляет собой и качество, и свойство права, но не принцип права, также имеет место быть [14, с. 24].

Отсутствие единообразия в терминологии прослеживается и в практике Конституционного Суда, анализ решений которого позволил выявить следующие значения категории правовой определённости:

1. Принцип, требование и критерий правовой определённости. Данные формы выражения правовой определённости целесообразно рассматривать в комплексе, так как при решении вопроса о соблюдении или нарушении правовой определённости именно они используются в большей мере органом конституционного правосудия.

В практике Конституционного Суда категории «принцип» и «требование» («критерий») не являются совпадающими.

Во-первых, принцип правовой определённости используется Конституционным Судом как самодостаточный наряду с другими общеправовыми и конституционными принципами, такими как поддержание доверия к закону и действиям государства (см., например, постановления от 14.01.2020 № 2-П, от 14.11.2018 № 41-П, от 10.07.2018 № 30-П), справедливость (см., например, постановления от 17.11.2016 № 25-П, от 14.01.2016 № 1-П), всеобщее уважение прав человека и основных свобод (см., например, постановления от 26.03.2020 № 13-П, от 16.07.2015 № 22-П) и др.

Во-вторых, принцип правовой определённости имеет универсальный характер. Действие рассматриваемой идеи распространяется на многие сферы правового регулирования, отрасли права и даже правовые институты. Ярким тому примером является включение принципа правовой определённости в число принципов института юридической ответственности, на что неоднократно указывал Конституционный Суд в своих постановлениях (см., например, постановления от 26.03.2020 № 13-П; от 16.07.2015 № 22-П). 
В-третьих, принцип правовой определённости включает в себя определённые требования (элементы), соблюдение которых способствует реализации данного принципа. Среди таких требований Конституционный Суд выделяет, в частности, требования ясности, недвусмысленности и согласованности правовых норм, res judicata и иные требования, которые будут рассмотрены ниже.

В отличие от принципа правовой определённости, требование (критерий) правовой определённости, как правило, не носит самостоятельного характера и является составной частью различных правовых принципов. В частности, как уже было сказано выше, в некоторых случаях требование определённости, означающее ясность и недвусмысленность правовой нормы, является составной частью более обширного принципа правовой определённости. Кроме того, требование (критерий) правовой определённости может вытекать из принципов правового государства, верховенства закона, юридического равенства и иных общеправовых принципов (см, например, постановления Конституционного Суда РФ от 22.04.2020 № 20-П, от 15.04.2020 № 18-П от 26.04.2016 № 13-П).

Таким образом, категория «принцип правовой определённости» шире, чем «требование» или «критерий» рассматриваемого явления. Принцип обладает самостоятельным и универсальным характером, а требование (критерий) является обязательным элементом некоторых общеправовых и конституционных принципов.

2. Степень правовой определённости. Степень определённости является оценочной категорией. Нормативно-правовые акты могут быть более или менее определёнными по своему содержанию. Достаточная степень определённости правовой нормы заключается в недопущении двусмысленного понимания прав и обязанностей субъекта правоотношений, возможности предвидеть последствия своего поведения и в отсутствии «почвы» для произвола и злоупотреблений. Как неоднократно указывал Конституционный Суд, «необходимая степень определённости может быть достигнута не только посредством анализа одного или нескольких находящихся во взаимосвязи нормативных положений, но и путём выявления более сложной взаимосвязи правовых предписаний, в том числе на основе обобщения судебной практики применительно к конкретной сфере общественных отношений и с учётом особенностей реализуемых прав и законных интересов граждан» (см., например, постановления от 18.07.2019 № 29-П, от 12.03.2015 № 4-П; от 23.09.2014 № 24-П, 26.06.2014 № 19-П).

На основе анализа практики Конституционного Суда можно прийти к выводу, что оценка степени определённости правового регулирования проводится с целью понимания того, соответствует ли правовая норма или совокупность правовых норм принципу или требованию определённости. Поэтому взаимосвязь между категориями «степень» и «принцип», «требование», «критерий» проявляется в том, что степень определённости и её выраженность влияют на установление факта соблюдения требований определённости. Иными словами, если правовая норма обла- 
дает достаточной степенью определённости, то принцип, требование или критерий правовой определённости является соблюдённым.

3. Состояние и ситуация правовой определённости. В решениях Конституционного Суда данные категории рассматриваются сквозь призму неопределённости. Например, в постановлениях от 26.06.2014 № 19-П и от 27.06.2013 № 15-П Конституционный Суд указывает на необходимость исключения необоснованно продолжительного сохранения ситуации неопределённости в отношении правового статуса субъекта правоотношений, а в постановлении от 10.03.2016 № 7-П он говорит о состоянии неопределённости относительно положения должника.

Представляется, состоянием или ситуацией правовой неопределённости в контексте решений высшего органа конституционного правосудия являются неблагоприятные последствия, возникшие вследствие существующего нарушения принципа или требования правовой определённости. Неблагоприятные последствия могут выражаться, в частности, в нарушении прав и произвольном изменении статуса участников правоотношений, непредсказуемости результата правового поведения, злоупотреблении полномочиями.

Реже в практике Конституционного Суда встречаются такие категории проявления правовой определённости, как «качество» (постановление Конституционного Суда РФ от 12.01.2018 № 2-П), «предписание» (постановление Конституционного Суда РФ от 01.07.2015 № 19-П), «режим» (постановление Конституционного Суда РФ от 22.03.2005 № 4-П), «мера» (определение Конституционного Суда РФ от 12.03.2019 № 579-О), а в одном из своих особых мнений судья Г. А. Гаджиев обозначил правовую определённость как «ценность» (постановление Конституционного Суда РФ от 02.12.2013 № 26-П).

Таким образом, анализ различных категорий, в которых может проявляться правовая определённость в практике конституционного правосудия, показал, что такие наиболее частые формы правовой определённости, как «принцип», «требование» и «степень», с одной стороны, «ситуация» и «состояние» - с другой, и «степень» - с третьей, имеют определённую взаимосвязь между собой, которую можно выразить по следующей формуле: ситуация (состояние) правовой неопределённости является негативным последствием несоблюдения принципа (требования, критерия) правовой определённости, возникшее вследствие недостижения достаточной степени определённости правового регулирования.

II. Требования и элементы принципа правовой определённости. На сегодняшний день существуют разные и, порой, даже противоречивые позиции по поводу элементов, составляющих правовую определённость. В первых решениях, где Конституционный Суд анализировал правовые нормы сквозь призму определённости или неопределённости, он указывал на ясность, недвусмысленность правовой нормы, обеспечение единообразного понимания и толкования нормы право- 
применителями. Однако спустя 20 лет содержание правовой определённости стало пониматься очень широко, особенно в юридической науке.

Ряд авторов рассматривают содержание правовой определённости традиционным образом в значении res judicata, что означает устойчивость, незыблемость, непоколебимость судебного решения, вступивщего в законную силу [1, с. 3, 10$]$.

Однако в последнее время появились научные работы, авторы которых рассматривают правовую определённость более широко. Так, О.Г. Подоплелова и О. Н. Кряжкова к числу проявлений принципа правовой определённости, в том числе, относят: защиту правомерных ожиданий, запрет обратной силь закона, требование nullum crimen, nulla роепа sine lege (нет преступления, нет наказания без указания в законе), non bis in idem (запрет двойной ответственности за одно и то же деяние), res judicata (признание законной силь судебных решений, их неопровержимость) [11, с. 53]. Н. Н. Ковтун и А. А. Зорин предлагают под правовой определённостью понимать: «а) точность и ясность правовых предписаний; б) исключение коллизионности действующих правовых предписаний и практики их применения; в) механизмы пересмотра судебных решений, вступивших в законную силу, должны обеспечивать его устойчивость и неопровержимость; г) окончательное судебное решение должно быть реально исполнено» [9, с. 145-146].

На наш взгляд, такая разноплановость понимания содержания принципа правовой определённости обусловлена, во-первых, его востребованностью и динамичным развитием в практике конституционной аргументации. Анализ решений Конституционного Суда позволяет рассматривать содержание принципа правовой определённости через выделение следующих элементов:

1. Требование формальной определённости правовых норм. Данный критерий включает в себя следующие составляющие:

- точность, ясность и недвусмысленность правовых норм (напр., постановления от 22.04.2020 № 20-П, от 25.06.2015 № 17-П, от 08.04.2014 № 10-П);

- согласованность и непротиворечивость правовых норм (постановления от 06.07.2018 № 29-П, от 10.11.2016 № 23-П, от 19.01.2016 № 2-П и др.);

- понятность нормативно-правового механизма для субъектов соответствующих правоотношений (постановления от 17.02.2015 № 2-П, от 22.04.2014 № 12-П, от 23.12.2013 № 29-П).

Конституционный Суд в своих решениях неоднократно раскрывал последствия несоблюдения вышеуказанных требований, проявляющихся в препятствии для адекватного уяснения содержания правового регулирования, возможности неограниченного усмотрения в прочессе правоприменения и осуществлении произвола, а также ослаблении гарантий защуиты конституционных прав и свобод. В связи с этим нарушение лишь требования определённости правовой нормы может быть вполне достаточно для признания такой нормы противоречащей Конституции. 


\section{2. Предсказуемость правового регулирования и предвидение правовых} последствий. Под предсказуемостью правового регулирования следует понимать возможность предвидения, ожидания и прогнозирования последствий совершаемого поведения. Поэтому взаимосвязь данных требований проявляется в том, что обеспечение предсказуемости правового регулирования способствует возможности индивида предвидеть последствия от выбранной им модели поведения [15, с. 73] (см., напр., постановление Конституционного Суда от 15.04.2020 № 18-П).

Говоря о месте и роли данного требования принципа правовой определённости, следует отметить, что, по мнению Г. А. Гаджиева, высказанному им к постановлению Конституционного Суда от 27.03.20212 № 8-П, «принц̧ип правовой определённости представляет собой иирокую концепцию, стержнем которой является предсказуемость правового регулирования». Действительно, роль предсказуемости правового регулирования и возможности предвидеть последствия совершаемого поведения очень важна и заключается в придании участникам общественных отношений уверенности в неизменности их официально признанного статуса и действенности государственной защиты наполняющих его прав, иными словами, в том, что возникшее у них на основе действующего законодательства право будет уважаться властями и будет реализовано (см., например, определения от 26.03.2019 № 756-О, от 18.09.2014 № 1819-О, от 03.07.2014 № 1565-О). Между тем, из практики Конституционного Суда следует, что в большей степени рассматриваемые требования являются вытекающими из требований точности и чёткости правовых предписаний, которые позволяют участникам соответствующих правоотношений сообразовывать своё поведение и на основе обладающих ясностью предписаний осознавать правовые последствия (см., например, определения от 26.03.2020 № 805-О, от 18.07.2019 № 1896-О).

3. Стабильность. В контексте принципа правовой определённости стабильность следует рассматривать в двух смыслах: формальном и процессуальном.

В формальном смысле стабильность понимается как требование принципа правовой определённости, означающее устойчивость правового регулирования и сложившейся системы правоотношений. Такое значение стабильности придаёт Конституционный Суд, к примеру, в своём постановлении от 17.01.2019 № 4-П, по смыслу которого «стабильность правоотношений составляет ядро принциипа правовой определённости», а также в постановлении от 10.10.2013 № 20-П, согласно которому «приничип правовой определённости включает в себя требования стабильности правопорядка $и$ устойчивости сложивиейся системы правоотношений». В этом смысле стабильность тесно связана с предсказуемостью правового регулирования, так как она способствует существованию возможности лица быть уверенным в неизменности своего правового статуса и пониманию последствий своего поведения.

В процессуальном смысле стабильность рассматривается как устойчивость судебных актов и является проявлением свойства res judicata, о чём речь пойдёт в следующем пункте. 
4. Res judicata. Свойство res judicata является, пожалуй, требованием правовой определённости, наиболее изучаемым в юридической науке. Res judicata нашло своё выражение в ст. 6 Европейской конвенции по правам человека и пришло в практику конституционного правосудия из практики Европейского Суда по правам человека. При решении вопроса о соблюдении анализируемого требования Конституционный Суд неоднократно, в том числе в постановлении от 17.10.2017 г. № 24-П, определениях от 14.01.2016 № 14-О, от 16.07.2015 № 1618-О), подтверждал содержание res judicata ссылками на известные решения ЕСПЧ (например, постановления от 28.10.1999 по делу «Брумареску (Brumarescu) против Румынии», от 24.07.2003 по делу «Рябых против России», от 18.01.2007 по делу «Кот против России», от 31.07.2008 по делу «Проценко против России»)

Большинство учёных-правоведов считают, что res judicata является одним из аспектов принципа правовой определённости $[8$, с. 41-42; 16, с. 7] . В общем виде res judicata подразумевает недопустимость повторного рассмотрения разрешённого дела. По смыслу позиций Конституционного Суда, указанное требование включает в себя следующие элементы:

- признание законной силы судебных решений (постановления от 21.01.2020 № 3-П, от 12.11.2018 № 40-П, от 17.10.2017 № 24-П);

- окончательность и неопровержимость судебных решений (постановления от 18.03.2014 № 5-П, от 02.12.2013 № 26-П, определение от 08.12.2011 № 1616-О-О);

- общеобязательность судебных актов (определения от 23.04.2020 № 983-О, от 29.05.2012 № 1033-О);

- стабильность судебных актов (постановления от 20.02.2006 № 1-П, от 17.11.2005 № 11-П, определение от 20.12.2016 № 2685-О);

- исполнимость судебных решений (постановления от 12.07.2018 № 31-П, от 04.10.2016 № 18-П, от 21.12.2011 № 30-П).

Помимо рассматриваемых требований принципа правовой определённости в литературе встречаются мнения о необходимости выделения в качестве одного из проявлений принцип «nullum crimen, nulla poena sine lege». Данный принцип нашёл своё выражение в ст. 7 Конвенции по правам человека и дословно означает «нет преступления, нет наказания без указания на то в законе».

В отличие от res judicata, в отношении которого Конституционный Суд прямо предписывает его включение в содержание принципа правовой определённости, nullum crimen, nulla poena sine lege является самостоятельным и, как неоднократно утверждал Конституционный Суд, общепризнанным правовым принципом, закреплённым в ч. 2 ст. 54 Конституции (см., например, определения Конституционного Суда от 26.03.2020 № 810-О, 28.02.2019 № 536-О). Взаимосвязь между рассматриваемым принципом и правовой определённостью прослеживается в некоторых решениях органа конституционного контроля: «В сфере уголовно-правового регулиро- 
Шишкина О. Е., Бурцева С. С. Правовая определённость в практике Конституционного Суда Российской Федерации

вания - в силу статьи 54 (часть 2) Конституции РФ, основанной на принциие nullum crimen, nulla poеna sine lege (нет преступления, нет наказания без указания на то в законе), - особое значение приобретает требование определённости правовых норм...», роль которого заключается «в точном и недвусмысленном определении признаков противоправного деяния в уголовном законе, непротиворечиво вписывающемся в общую систему правового регулирования» (см., например, постановление Конституционного Суда от 10.02.2017 № 2-П, определения Конституционного Суда от 27.09.2019 № 2357-О, от 17.07.2018 № 2048-О).

Таким образом, мы полагаем, что принцип nullum crimen, nulla sine lege и требование определённости правовых норм соотносится как общее и частное. Требование правовой определённости входит в содержание принципа «нет преступления, нет наказания без указания на то в законе» и способствует точному определению противоправного деяния в соответствующем правовом акте.

Аналогично данному принципу предлагают рассматривать non bis in idem (запрет двойной ответственности за одно и то же деяние), нашедший своё выражение в ч. 1 ст. 50 Конституции, как составляющую правовой определённости. Так, ряд учёных в содержании принципа правовой определённости выделяют процессуальную сторону принципа non bis in idem, предполагающего запрет повторного осуществления уголовного преследования лица за преступление, за которое это лицо уже было осуждено или оправдано, и тем самым гарантирующего лицу неизменность его правового положения (стабильность окончательно определённого статуса) [18, с. 153; 9, с. 146]. Вместе с тем, в практике конституционного правосудия данный подход не нашёл своего отражения. Напротив, Конституционный Суд выделяет правило non bis in idem в качестве независимого конституционного принципа, имеющего общее значение (см., например, определения Конституционного Суда от 27.02.2020 № 312-О, от 17.07.2018 № 2025-О).

Кроме того, в сложившейся практике неоднозначно решается вопрос о выделении требования поддержания доверия к закону как одного из аспектов правовой определённости. Так, например, согласно постановлению Конституционного Суда от 14.11.2018 № 41-П, постановлению Конституционного Суда от 10.07.2018 № 30-П Суд рассматривает принцип правовой определённости и поддержания доверия к закону как два разных, но взаимосвязанных критерия надлежащего правового регулирования. Между тем, в постановлении Конституционного Суда РФ от 17.01.2019 № 4-П орган конституционного контроля указывает, что «требования поддержания доверия к закону и стабильности гражданских правоотношений составляют ядро принципа правовой определённости, имеющего универсальное значение в отношениях государства и индивида». Думается, что такой подход размывает границы как рассматриваемого принципа, так и требования поддержания доверия к закону и усиливает существующую неоднозначность их содержания, роли и места среди иных конституционных принципов.

Таким образом, содержание общеправового принципа правовой определённости понимается широко и разнопланово как в юридической науке, так и в судебной практике 
органа конституционного правосудия. С учётом сложившейся практики Конституционного Суда можно сделать вывод о том, что содержание указанного принципа включает в себя такие требования, как формальная определённость, предсказуемость правового регулирования и предвидение правовых последствий, стабильность и res judicata.

Заключение. Правовая определённость имеет многоаспектный характер. Правовую определённость можно рассматривать как «принцип», «требование», «критерий», «степень», «состояние», «ситуация», а также «качество», «предписание», «режим», «мера». Данные категории взаимосвязаны между собой и отражают различные стороны явления правовой определённости.

Более того, сам принцип правовой определённости обладает обширным содержанием. Это во многом обусловлено тем, что правовая определённость является частью конституционной аргументации, которая находится в состоянии динамики, а не статики. Мы, в свою очередь, на основе сложившейся на сегодняшний день практики Конституционного Суда предлагаем выделять в содержании принципа правовой определённости такие элементы: требование формальной определённости, предсказуемость правового регулирования и предвидение правовых последствий, стабильность и свойство res judicata. Однако содержание рассматриваемого принципа, безусловно, нуждается в дальнейшем изучении и конкретизации с учётом дальнейшей деятельности органа конституционного контроля России, других судов.

\section{Список литературы}

1. Алексеева, Т. М. Правовая определённость судебных решений в уголовном судопроизводстве: понятие, значение и пределы : дис. ... канд. юрид. наук : 12.00.09 / Т. М. Алексеева. - Москва, 2015. - 263 с.

2. Велиева, Д. С. Содержание конституционного принципа правовой определённости: стандарты «качества закона» и правоприменительные императивы / Д. С. Велиева, М. В. Пресняков // Вестник Поволжского института управления. 2019. - Т. 19, № 6. - С. 4-17.

3. Витрук, Н. В. Конституционное правосудие в России (1991-2001): очерки теории и практики / Н. В. Витрук. - Москва : Городец-издат, 2001. - 508 с.

4. Витрук, Н. В. Общая теория юридической ответственности : монография / Н. В. Витрук. - Москва : Норма : ИНФРА-М, 2020. - 432 с.

5. Дербышева, Е. А. Место принципа правовой определённости в системе принципов российского права // Право и политика. - 2017. - № 2. - C. 29-41. - URL: https://nbpublish.com/library_read_article.php?id=21817 (дата обращения: 03.06.2020).

6. Должиков, А. В. Уже пора умом Россию понимать? Требование пригодности в конституционном правосудии // Сравнительное конституционное обозрение. 2020. - № 6 (139). - С. 51-86. 
7. Евлоев, И. М. Правовая определённость: принцип или критерий? // Актуальные проблемы теории и практики конституционного судопроизводства : сборник научных работ. Вып. 7. - Казань, 2012. - С. 250-256.

8. Ковтун, Н. Н. Правовая определённость и res judicata в решениях Европейского Суда по правам человека / Н. Н. Ковтун, Д. М. Шунаев // Российский судья. 2014. - № 9. - С. 38-42.

9. Ковтун, Н. Н. Принцип правовой определённости в системе правовых позиций и итоговых выводов Конституционного Суда РФ / Н. Н. Ковтун, А. А. Зорин // Вестник Волгоградского государственного университета. Серия 5 : Юриспруденция. - 2015. - № 3 (28). - С. 143-149.

10. Кряжкова, О. Как изменится Конституционный Суд. Первые впечатления от обновлённой законодательной модели // Адвокатская газета. - 10 ноября 2020 г. - URL: https://www.advgazeta.ru/mneniya/kak-izmenitsya-konstitutsionnyy-sud/ (дата обращения 18.03.2021).

11. Кряжкова, О.Н. Стратегия защиты в Конституционном Суде России / О. Н. Кряжкова, О. Г. Подоплелова. - Москва : Институт права и публичной политики, 2018. - 196 с.

12. Морозова, Л. А. Правовая определённость как общеправовой универсальный принцип реализации права // Социально-экономические явления и процессы. 2017. - № 3. - С. 250-256.

13. Несмеянова, С. Э. Правовые проблемы становления специализированного конституционного контроля в Российской Федерации : дис. ... канд. юрид. наук : 12.00.02 / С. Э. Несмеянова. - Екатеринбург, 1994. - 172 с.

14. Пресняков, М. В. Правовая определенность как качество права // Гражданин и право. -2012 . - № 10. - С. 20-35.

15. Рукавишникова, А. А. Генезис категории «правовая определённость» в современной юридической науке // Вестник Томского государственного университета. Право. - 2014. - № 3 (13). - С. 70-83.

16. Самсонов, Н. В. Действие принципов правовой определённости и res judicata в гражданском процессе (в свете постановления Конституционного Суда Российской Федерации от 17 октября 2017 г. № 24-П) // Арбитражный и гражданский процесс. - 2018. - № 3. - С. 6-11.

17. Сидоренко, А. И. Принцип правовой определенности в судебной практике: имплементация решений Европейского Суда по правам человека : дис. ... канд. юрид. наук : 12.00.01 / А. И. Сидоренко. - Пермь, 2016. - 183 с.

18. Сидоренко, М. В. Правовая определённость как предмет правовых позиций и итоговых выводов Конституционного Суда России // Пробелы в российском законодательстве. - 2015. - № 5. - С. 152-154. 
19. Чимакадзе, Ф. В. Правовая определённость: принцип или явление? // Принципы права: проблемы теории и практики : материалы VII всерос. науч.-практ. конф. Ч. 3. - Москва, 2017. - С. 49-56.

20. Шульженко, Ю. Л. Конституционный контроль в России / Ю. Л. Шульженко ; РАН. Ин-т государства и права. - Москва, 1995. - 175 с.

\section{References}

1. Alekseeva T. M. Pravovaya opredelennost' sudebnykh reshenii v ugolovnom sudoproizvodstve: ponyatie, znachenie i predely [Legal certainty of court decisions in criminal proceedings: concept, meaning and limits]. Cand. Dis. (Legal Sci.). Moskow, 2015. 263 p.

2. Velieva D. S., Presnyakov M. V. Soderzhanie konstitutsionnogo printsipa pravovoi opredelennosti: standarty «kachestva zakona» i pravoprimenitel'nye imperativy [Content of the constitutional principle of legal certainty: "Law Quality" standards and law enforcement imperatives]. Vestnik Povolzhskogo instituta upravleniya, 2019, vol. 19, no. 6, pp. 4-17.

3. Vitruk N. V. Konstitutsionnoe pravosudie v Rossii (1991-2001): ocherki teorii i praktiki [Constitutional justice in Russia (1991-2001): essays on theory and practice]. Moscow: Gorodets-publ., 2001. 508 p.

4. Vitruk N. V. Obshchaya teoriya yuridicheskoi otvetstvennosti [General theory of legal liability. Monograph]. Moscow: Norma:INFRA-M Publ., 2020. 432 p.

5. Derbysheva E. A. Mesto printsipa pravovoi opredelennosti $v$ sisteme printsipov rossiiskogo prava [Place of the principle of legal certainty in the system of principles of Russian law]. Pravo $i$ politika, 2017, no. 2, pp. 86-92. Available at: https://nbpublish.com/library_read_article.php?id=21817 (accessed 03 June 2020).

6. Dolzhikov A. V. Uzhe pora umom Rossiyu ponimat'? Trebovanie prigodnosti v konstitutsionnom pravosudii [Is it time to understand Russia rationally? Test of suitability in constitutional adjudication]. Sravnitel'noe konstitutsionnoe obozrenie, 2020, no. 6 (139), pp. 51-86.

7. Evloev I. M. Pravovaya opredelennost': printsip ili kriterii? [Legal certainty: principle or criterion?]. In: Aktual'nye problemy teorii i praktiki konstitutsionnogo sudoproizvodstva: sbornik nauchnykh rabot, vyp. 7 [Actual problems of the theory and practice of constitutional proceedings. Collection of scientific papers, vol. 7]. Kazan, 2012, pp. 250-256.

8. Kovtun N. N., Shunaev D. M. Pravovaya opredelennost' i res judicata v resheniyakh Evropeiskogo Suda po pravam cheloveka [Legal certainty and res judicata in decisions of the European Court of human rights]. Vestnik Volgogradskogo gosudarstvennogo universiteta. Ser. 5: Yurisprudentsiya, 2015, no. 3 (28), pp. 143-149.

10. Kryazhkova O. Kak izmenitsya Konstitutsionnyi Sud. Pervye vpechatleniya ot obnovlennoi zakonodatel'noi modeli [How the Constitutional Court will change. First impressions of the updated legislative model]. Advokatskaya gazeta, 2020, November 10. 
Available at: https://www.advgazeta.ru/mneniya/kak-izmenitsya-konstitutsionnyy-sud/ (accessed 18 March 2021).

11. Kryazhkova O. N., Podoplelova O. G. Strategiya zashchity v Konstitutsionnom Sude Rossii [Defense strategy in the Constitutional Court of Russia]. Moscow : Institute of Law and Public Policy, 2018. 196 p.

12. Morozova L. A. Pravovaya opredelennost' kak obshchepravovoi universal'nyi printsip realizatsii prava [Legal certainty as a general legal universal principle of the exercise of law]. Sotsial'no-ekonomicheskie yavleniya i protsessy, 2017, no. 3, pp. 250-256.

13. Nesmeyanova S. E. Pravovye problemy stanovleniya spetsializirovannogo konstitutsionnogo kontrolya $v$ Rossiiskoi Federatsii [Legal problems of the formation of specialized constitutional control in the Russian Federation]. Yekaterinburg, 1994, 172 p.

14. Presnyakov M. V. Pravovaya opredelennost' kak kachestvo prava [Legal certainty as a quality of law]. Grazhdanin i pravo, 2012, no. 10, pp. 20-35.

15. Rukavishnikova A. A. Genezis kategorii «pravovaya opredelennost'» v sovremennoi yuridicheskoi nauke [Genesis of the category «legal certainty» in modern legal science]. Vestnik Tomskogo gosudarstvennogo universiteta. Pravo, 2014, no. 3 (13), pp. 70-83.

16. Samsonov N. V. Deistvie printsipov pravovoi opredelennosti i res judicata v grazhdanskom protsesse (v svete postanovleniya Konstitutsionnogo Suda Rossiiskoi Federatsii ot 17 oktyabrya 2017 goda № 24-P) [Operation of principles of legal certainty and res judicata in the civil procedure (in view of resolution no. 24-п of the Constitutional Court of the Russian Federation dd. October 17, 2017)]. Arbitrazhnyi i grazhdanskii protsess, 2018, no. 3, pp. 6-11.

17. Sidorenko A. I. Printsip pravovoi opredelennosti v sudebnoi praktike: implementatsiya reshenii Evropeiskogo Suda po pravam cheloveka [Principle of legal certainty in judicial practice: implementation of decisions of the European Court of Human Rights]. Cand. Dis. (Legal Sci.). Perm, 2016. 183 p.

18. Sidorenko M. V. Pravovaya opredelennost' kak predmet pravovykh pozitsii i itogovykh vyvodov Konstitutsionnogo Suda Rossii [Legal certainty as a subject of legal positions and final conclusions of the Constitutional Court of Russia]. Probely v rossiiskom zakonodatel'stve, 2015, no. 5, pp. 152-154.

19. Chimakadze F. V. Pravovaya opredelennost': printsip ili yavlenie? [Legal certainty: principle or phenomenon?]. In: Printsipy prava: problemy teorii i praktiki: materialy VII Vserossiiskoi nauchno-prakticheskoi konferentsii, ch. 3 [Principles of Law: Problems of Theory and Practice: Materials of the VII All-Russian Scientific and Practical Conference, Part 3]. Moscow, 2017, pp. 49-56.

20. Shul'zhenko Yu. L. Konstitutsionnyi kontrol'v Rossii [Constitutional control in Russia]. Moscow: Institute of State and Law Publ., 1995. 175 p. 